\title{
Peningkatan Prestasi Belajar Agama Hindu Berbasis Model Ekspositori Melalui Diskusi Interaktif
}

\section{Luh Siah*}

SMP Negeri 3 Sawan, Buleleng, Indonesia

\section{A R T I C L E I N F O \\ Article history: \\ Received 20 May 2018 \\ Received in revised form 26 June 2018 \\ Accepted 09 July 2018 \\ Available online 27 \\ August 2018}

\section{Kata Kunci:}

Model Ekspositori;

Diskusi Interaktif;

Prestasi Belajar; Agama

Hindu

Keywords:

Expository Model;

Interactive Discussion;

Learning Achievement;

Hindu Religion

\begin{abstract}
A B S T R A K
Penelitian ini dilaksanakan di SMP Negeri 3 Sawan kelas VIII A3 yang prestasi belajarnya masih rendah. Tujuan penulisan penelitian tindakan kelas ini adalah untuk mengetahui apakah model pembelajaran Ekspositori dengan diskusi interaktif dapat meningkatkan prestasi belajar siswa. Metode pengumpulan datanya adalah tes prestasi belajar. Metode analisis datanya adalah deskriptif. Hasil yang diperoleh dari penelitian ini adalah model ekspositori dengan diskusi interaktif dapat meningkatkan prestasi belajar siswa. Ini terbukti dari hasil yang diperoleh pada pada awalnya 18\% yang tuntas mencapai Kriteria Ketuntasan Minimum (KKM) setelah diberikan tindakan pada siklus I meningkat menjadi 34,61\% dan pada siklus II meningkat lagi menjadi $85 \%$. Kesimpulan yang diperoleh dari penelitian ini adalah model ekspositori dengan diskusi interaktif dapat meningkatkan prestasi belajar siswa kelas VIII A3 SMP Negeri 3 Sawan.
\end{abstract}

\section{A B S T R A C T}

This research was carried out at SMP Negeri 3 Sawan class VIII A3 whose learning achievement was still low. The purpose of writing class action research is to find out whether the Expository learning model with interactive discussion can improve student learning achievement. The data collection method is a learning achievement test. The data analysis method is descriptive. The results obtained from this study are expository models with interactive discussions can improve student learning achievement. It is evident from the results obtained at first $18 \%$ of those who reached the Minimum Completeness Criteria (KKM) after being given the action in the first cycle increased to $34.61 \%$ and in the second cycle increased again to $85 \%$. The conclusion obtained from this study is that the expository model with interactive discussion can improve the learning achievement of grade VIII A3 students of SMP Negeri 3 Sawan.

\footnotetext{
* Corresponding author.

E-mail addresses: luhsiah3@gmail.com
} 


\section{Pendahuluan}

Pelajaran agama yang kebanyakan bersifat abstrak terkadang sangat sulit untuk dipahami oleh sebagian besar siswa. Pada zaman sekarang belajar agama sering dianggap sebagai sesuatu yang kurang menarik, karena para siswa lebih mengutamakan pelajaran yang bersifat moderen seperti bahasa asing maupun pelajaran eksak agar bisa cepat memperoleh pekerjaan setelah tamat.

Pendidikan agama Hindu dimaksudkan untuk membentuk peserta didik menjadi manusia yang beriman dan bertaqwa terhadap Tuhan Yang Maha Esa serta peningkatan potensi spiritual. Peningkatan potensi spiritual termasuk pemahaman, pengenalan, nilai-nilai keagamaan dalam kehidupan siswa seharihari. Peningkatan potensi spiritual tersebut bertujuan untuk mengoptimalkan berbagai potensi manusia yang mencerminkan harkat dan martabat manusia sebagai mahluk Tuhan.

Permendiknas RI No. 41 tahun 2007 yang menyebutkan bahwa proses pembelajaran pada setiap satuan pendidikan dasar dan menengah harus interaktif, inspiratif, menyenangkan, menantang, dan memotivasi peserta didik untuk berpartisipasi aktif serta memberikan ruang yang cukup bagi prakarsa, kreativitas dan kemandirian sesuai dengan bakat, minat, dan perkembangan fisik serta psikologis peserta didik. Karena itu orientasi pembelajaran harus ditekankan kepada peserta didik sebagai subjek, yang harus aktif dan kreatif melaksanakan proses pembelajaran dengan arahan dan bantuan dari guru. Guru dalam hal ini harus betul-betul aktif memerankan dirinya sebagai fasilitator, motivator dan lain-lain untuk peningkatan prestasi dan mampu mensyukuri karunia Tuhan.

Pendidikan akan lebih bermakna bagi anak apabila pengetahuan dibangun dengan dasar informasi yang diperoleh secara alami. Untuk tujuan tersebut, lingkungan belajar harus dibangun sedemikian rupa untuk memberikan pemahaman dan menjelaskan secara jelas teori-teori atau konsepkonsep yang disampaikan kepada anak, agar lebih bermakna serta dasar pengetahahuan dapat dimanfaatkan anak dalam kehidupan sehari-hari. Oleh karena itu ilmu pengetahuan harus dibangun secara bertahap dan sedikit demi sedikit sesuai dengan tahap perkembangan kemampuan anak.

Hal yang tidak kalah pentingnya adalah pemahaman guru tentang proses pembelajaran dapat berlangsung aktif, kreatif dan menarik. Hal ini akan bisa terjadi bila dalam diri siswa tumbuh rasa ingin tahu, mencari jawaban atas pertanyaan, memperluas dan memperdalam pemahaman dengan menggunakan metode yang efektif. Rasa ingin tahu siswa muncul dan terlihat ketika sudah mulai mengajukan pertanyaan-pertanyaan. Pertanyaan inilah nantinya yang akan menjadi bahan pembelajaran untuk dicari jawabannya bersama-sama antara guru dan siswa. Agar mampu menjawab semua pertanyaan yang dilontarkan siswa dan memberikan dampak yang baik terhadap kelangsungan pembelajaran mereka, seorang guru harus benar-benar memiliki pengetahuan yang mendalam tentang materi yang diajarkan sehingga dia layak disebut seorang guru yang kompeten.

Berdasarkan hasil pengamatan dan pengalaman bahwa kegiatan belajar mengajar pendidikan Agama Hindu sering menjadi kurang menarik bagi siswa karena dianggap sebagai pelajaran yang membosankan yang memerlukan latihan-latihan banyak yang monoton, lewat persembahyanganpersembahyangan sehingga membuat siswa semakin jenuh karena sebagai manusia masih lebih senang dengan kebebasan. Oleh karenanya guru dituntut untuk mampu menciptakan suasana belajar yang tidak membosankan. Dengan demikian, siswa dapat menerima apa yang telah disampaikan oleh guru sehingga hasil belajar akan maksimal.

Untuk mewujudkan hal itu, guru memiliki peran yang sangat penting ketika melakukan proses pembelajaran. Selain itu guru juga harus mampu memilih dan menerapkan strategi pembelajaran dalam proses kegiatan belajar mengajar supaya proses tersebut berhasil dengan baik dan bermanfaat bagi siswa untuk mengembangkan kemampuan pada siswa baik kemampuan kognitif, afektif maupun psikomotorik salah satunya dengan menggunakan model pembelajaran ekspositori.

Model pembelajaran ekspositori merupakan cara penyampaian pelajaran dari seorang guru kepada siswa di dalam kelas dengan cara berbicara di awal pelajaran, menerangkan materi dan contoh soal disertai tanya jawab.

Model pembelajaran ekspositori juga diartikan sebagai cara pembelajaran yang menekankan kepada proses penyampaian materi secara verbal dari seorang guru kepada sekolompok siswa dengan maksud agar siswa dapat menguasai materi pelajaran secara optimal artinya siswa memahami apa yang telah disampaiakan oleh guru.

Pada dasarnya model ekspositori merupakan bentuk dari pendekatan pembelajaran yang berorientasi kepada guru. Diamana melalui strategi ini guru memegang peran sangat dominan. Guru menyampaikan materi pembelajaran secara terstruktur dengan harapan materi pelajaran yang disampaikan itu dapat dikuasai siswa dengan baik dan benar. Jadi, dalam proses pembelajaran, strategi pembelajaran mempunyai peran yang cukup besar dalam kegiatan belajar mengajar. Salah satu cara yang bisa digunakan agar siswa tidak lagi bosan dalam belajar adalah dengan menggunakan model 
pembelajaran ekspositori. Model pembelajaran ekspositori mempunyai peranan yang sangat penting untuk mencapai tujuan dalam kegiatan pembelajaran, karena fokus utama strategi ini adalah kemampuan akademik siswa, sehingga guru akan lebih aktif, kreatif dan inovatif dalam menyampaikan materi yang akan disampaikannya. Penggunaan strategi yang tepat akan dapat mempercepat proses pencapaian tujuan dari suatu pembelajaran. Kita ketahui berhasil tidaknya suatu usaha atau kegiatan banyak tergantung pada tujuan yang hendak dicapai oleh orang atau lembaga yang melaksanakannya.

Rendahnya prestasi siswa khusus bidang agama Hindu dapat juga penulis kemukakan berdasarkan nilai tes Ulangan Harian (UH) untuk kelas VIII A3. Khusus materi agama Hindu, menunjukkan bahwa baru sekitar $18 \%$ siswa atau sekitar 4 siswa yang mencapai kreteria ketuntasan minimal (KKM) dari 76 KKM yang di tetapkan. Hal ini menyebabkan sekitar 82\% siswa atau sekitar 22 siswa perlu meningkatkan pelaksanaan pembelajaran. Kenyataan ini menunjukkan bahwa sebenarnya masih perlu ada upaya-upaya yang harus dilaksanakan untuk meningkatkan hasil belajar siswa. Maka dalam hal ini yang menjadi tujuan di dalam penelitian ini adalah untuk meningkatkan prestasi belajar Agama Hindu dengan menerapkan Model Ekspository dengan diskusi interaktif siswa kelas VIII A3 di SMP N 3 Sawan pada semester genap tahun pelajaran 2017/2018.

\section{Metode}

Desain penelitian ini adalah Penelitian Tindakan Kelas (PTK) atau classroom action research. Secara umum PTK bertujuan untuk meningkatkan dan memperbaiki kualitas proses pembelajaran di kelas yang mengalami masalah pembelajaran. Penelitian ini berlangsung dalam dua siklus dengan setiap siklus terdiri atas empat tahap, yaitu perencanaan tindakan, pelaksanaan tindakan, observasi/evaluasi serta refleksi (Kemmis \& Taaggart, 1998).

Subjek penelitian ini adalah siswa kelas VIII A 3 SMP Negeri 3 Sawan yang berjumlah 26 siswa yang terdiri dari 15 siswa laki-laki dan 11 siswa perempuan dengan karakteristik yang berbeda, baik prestasi maupun tingkat sosial ekonomi. Pengambilan kelas VIII A3 ini sebagai objek penelitian dikarenakan kelas VIII A3 memiliki prestasi kelas yang lebih rendah dengan nilai rata-rata sebesar 55 sehingga diperlukan adanya tindakan untuk meningkatkan kemampuan siswa. Adapun nilai kelas VIII A3 dalam materi sebelumnya kurang dari kriteria ketuntasan belajar yaitu 76 dibandingkan dengan kelas lainnya. Di samping hal tersebut, siswa kelas VIII A3 sebagian besar masih cenderung malas membaca materi yang akan dipelajari. Sehingga rasa ingin tahu siswa kurang terhadap pembelajaran Agama Hindu. Karena rasa ingin tahu yang kurang inilah yang menyebabkan siswa kurang dalam mengajukan pertanyaan jika ada yang kurang dimengerti, mengemukakan pendapat serta memberikan respons dalam proses pembelajaran. Sehingga Interaksi siswa dengan guru, siswa dengan siswa dan siswa dengan lingkungannya sangat kurang. Objek yang diteliti dalam penelitian ini adalah peningkatan prestasi belajar Agama Hindu siswa kelas VIII A3 Semester II tahun pelajaran 2017/2018 SMP Negeri 3 Sawan pada materi Veda setelah diterapkan model pembelajaran ekspositori dengan diskusi interaktif. Pelaksanaan penelitian ini sudah terjadwal yaitu mulai dari bulan Januari sampai bulan Maret tahun 2018.

Penelitian ini dibagi menjadi dua kegiatan yaitu refleksi awal dan pelaksanaan penelitian. Penelitian ini dilaksanakan dalam dua siklus, masing-masing siklus terdiri dari empat tahap. Empat kegiatan utama yang ada pada setiap siklus yaitu: perencanaan tindakan, pelaksanaan tindakan, observasi/evaluasi dan refleksi. Setiap siklus dilaksanakan dalam 3 kali pertemuan pembelajaran yang terdiri 2 pertemuan untuk pelaksanaan tindakan dan 1 kali pertemuan untuk melakukan tes akhir siklus. Desain penelitian ini dapat divisualkan pada Gambar 1.

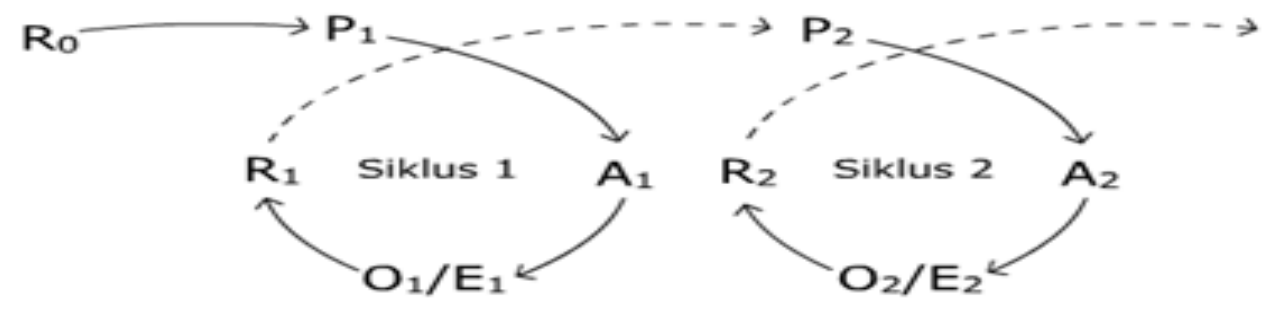

Gambar 1. Rancangan Penelitian Tindakan Kelas Dimodifikasi dari Kemmis \& McTaggart (dalam McNiff, 2002) 
Keterangan :

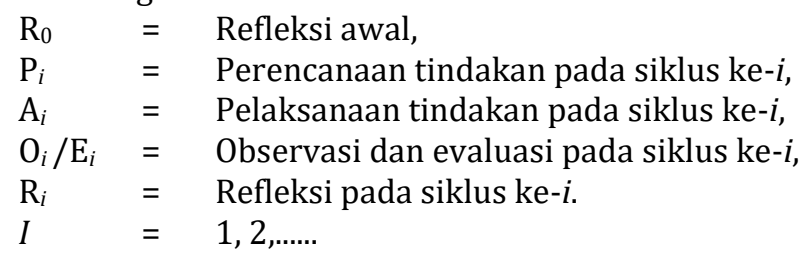

Tahapan penelitian yang dilaksanakan mengacu pada alur yang telah digambarkan pada Gambar 3.1. Dalam penelitian ini dilaksanakan suatu tindakan yang terdiri dari 2 siklus. Adapun tindakan yang dilaksanakan pada setiap siklus seperti terlihat pada Tabel 1.

Tabel 1. Langkah-langkah Pembelajaran dengan Model Ekspositori

\begin{tabular}{|c|c|c|}
\hline TAHAP & KEGIATAN GURU & KEGIATAN SISWA \\
\hline $\begin{array}{c}\text { Pendahuluan } \\
\text { (Menyampaikan } \\
\text { Tujuan dan } \\
\text { Memotivasi siswa) }\end{array}$ & $\begin{array}{l}\text { Guru menyampaikan tujuan pelajaran } \\
\text { yang akan dicapai pada pertemuan dan } \\
\text { menekankan pentingnya materi yang } \\
\text { akan dipelajari dan memotivasi siswa } \\
\text { belajar }\end{array}$ & $\begin{array}{l}\text { Siswa memperhatikan apa } \\
\text { yang disampaikan guru }\end{array}$ \\
\hline Inti & $\begin{array}{l}\text { - Guru menyampaikan materi dengan } \\
\text { ceramah, tanya jawab, dilanjutkan } \\
\text { demonstrasi untuk memperjelas } \\
\text { konsep terkait materi yang dijelaskan } \\
\text { yaitu terkait dengan materi Veda. } \\
\text { - Guru memberikan kesempatan bagi } \\
\text { siswa untuk bertanya sehingga terjadi } \\
\text { diskusi dalam kelas (diskusi } \\
\text { interaktif). } \\
\text { - Guru menyampaikan ringkasan atau } \\
\text { latihan-latihan soal setelah melakukan } \\
\text { penyampaian materi. }\end{array}$ & $\begin{array}{l}\text { Siswa meningkatkan } \\
\text { rasa ingin tahu dengan } \\
\text { menanyakan hal yang } \\
\text { kurang dimengerti. } \\
\text { - Siswa mengerjakan } \\
\text { latihan soal-soal yang } \\
\text { diberikan guru. }\end{array}$ \\
\hline Penutup & $\begin{array}{l}\text { - Guru memberikan kesempatan } \\
\text { kepada siswa untuk menyimpulkan } \\
\text { materi yang dipelajari. } \\
\text { - Guru memberikan evaluasi maupun } \\
\text { tugas-tugas untuk dikerjakan di } \\
\text { rumah }\end{array}$ & $\begin{array}{l}\text { - Siswa menyimpulkan } \\
\text { materi yang dipelajari. } \\
\text { - Siswa mencatat tuga-tugas } \\
\text { rumah yang diberikan } \\
\text { guru. }\end{array}$ \\
\hline
\end{tabular}

Dalam penelitian ini, jenis data yang diperlukan yaitui data tentang prestasi belajar Agama Hindu siswa. Instrumen yang digunakan dalam mengumpulkan data untuk mengukur prestasi belajar Agama Hindu siswa berupa tes prestasi belajar. Tes prestasi belajar Agama Hindu yang akan dipergunakan adalah tes objektif. Dalam penyusunan tes prestasi belajar matematika, terlebih dahulu dibuat kisi-kisi soal yang berfungsi sebagai peta tentang penyebaran butir soal, sehingga bahan, aspek intelektual, taraf kesukaran, jumlah soal dan persentasenya dapat tersebar secara merata. Tes prestasi belajar Agama Hindu yang telah disusun kemudian diujicobakan untuk mendapatkan gambaran secara empirik tentang kelayakan tes tersebut dipergunakan sebagai instrumen penelitian. Hasil uji coba dianalisis lebih lanjut untuk mendapatkan validitas dan reliabilitas tes.

Penelitian tindakan kelas ini menggunakan cara pengumpulan data yaitu dengan pemberian tes prestasi belajar. Sehubungan dengan data yang diperoleh dalam penelitian ini adalah data dalam bentuk angka maka dianalisis yang digunakan adalah metode analisis deskriptif. Untuk data kuantitatif dianalisis dengan mencari mean, median, modus, membuat interval kelas dan melakukan penyajian dalam bentuk tabel dan grafik. 


\section{Hasil dan pembahasan}

\section{Kondisi Pra-Siklus}

Deskripsi Berdasarkan hasil observasi awal yang peneliti lakukan sebelum melakukan penelitian diperoleh beberapa hal diantarannya:

1) Siswa kelas VIII A3 kesulitan dalam memahami materi yang diberikan karena siswa malas membaca materi yang akan dipelajari.

2) Siswa kelas VIII A3 kurang aktif dalam mengikuti pembelajaran.

3) Siswa kelas VIII A3 menganggap pelajaran Agama Hindu tidak penting dan membosankan.

4) Saat proses belajar mengajar siswa kelas VIII A3 jarang sekali yang mengajukan pertanyaan serta memberikan respon dalam proses pembelajaran di kelas.

Dengan kondisi seperti yang telah dipaparkan di atas, berimplikasi terhadap rendahnya prestasi belajar Agama Hindu. Rendahnya prestasi belajar siswa khususnya dalam bidang agama dapat dikemukakan berdasarkan nilai tes awal yang diberikan peneliti untuk kelas VIII A3. Khusus materi agama menunjukkan bahwa baru sekitar 18\% siswa yang mencapai kreteria ketuntasan minimal (KKM) yang ditetapkan. Hal ini menyebabkan sekitar $82 \%$ siswa perlu mengikuti remedial pada tes awal yang diberikan. Kenyataan ini menunjukkan bahwa sebenarnya masih perlu ada upaya-upaya yang harus dilaksanakan untuk meningkatkan prestasi belajar siswa. Upaya meningkatkan rasa ingin tahu pada materi yang dipelajari, meningkatkan pemahaman konsep dan meningkatkan interaksi antar guru dengan siswa serta siswa dengan siswa dilakukan dengan mengimplementasikan model pembelajaran ekspositori dengan diskusi interaktif. Jika dikategorikan rata-rata nilai tes awal siswa dalam pelajaran Agama Hindu berada pada kategori rendah karena masih berada dibawah Kriteria Ketuntasan Minimal (KKM) yaitu 76. Pembelajaran pada Siklus I

1) Rencana Tindakan Siklus I

Tahap perencanaan tindakan ini peneliti mengadakan persiapan atau perencanaan tindakan. Penelitian ini direncanakan dalam dua siklus dan setiap siklus dilaksanakan tiga kali pertemuan. Peneliti menyesuaikan rencana dengan jadwal yang telah disusun agar dalam pelaksanaannya tidak terkendala dengan hari- hari yang bisa mengganggu pelaksanaan penelitian. Menyusun rencana pelaksanaan pembelajaran. Berkonsultasi dengan teman-teman guru, membicarakan alat- alat peraga,bahan- bahan yang bisa membantu peningkatan prestasi belajar anak. Menyusun format penelitian, membuat bahan- bahan pendukung pembelajaran lainnya seperti menyiapkan, merancang skenario pembelajaran.

2) Pelaksanaan Tindakan Siklus I

1) Pada Melakukan pembelajaran inti explorasi dengan beberapa cara. Pertama, melibatkan peserta didik mencari infomasi yang luas tentang materi yang yang akan dipelajari. Kedua, menggunakan beragam pendekatan pembelajaran, media pembelajaran, dan sumber belajar. Selanjutnya, memfasilitasi terjadinya interaksi antar peserta didik,serta antara peserta didik dengan guru, dan terakhir melibatkan peserta didik dalam setiap langkah pembelajaran

2) Melakukan pembelajaran inti elaborasi dengan beberapa cara. Pertama, membiasakan peserta didik untuk membaca dan menulis yang beragam melalui tugas yang bermakna. Kedua, menyampaikan materi dengan ceramah, dan disertai dengan tanya jawab. Ketiga, memfasilitasi peserta didik melalui diskusi untuk memunculkan gagasan baru baik secara lisan maupun tertulis. Keempat, memfasilitasi peserta didik untuk membuat laporan hasil dikusi kelompoknya. Kelima, memfasilitasi peserta didik untuk menyampaikan hasil diskusinya di depan kelas.

3) Melakukan pembelajaran inti konfirmasi dengan beberapa cara. Pertama, memberikan penguatan dalam bentuk lisan maupun tulisan,isyarat atas keberhasilan peserta dididk dalam menyelesaikan tugasnya. Kedua, memberikan konfirmasi terhadap hasil eskplorasi, dan elaborasi peserta didik melalui beberapa sumber. Ketiga, memfasilitasi peserta didik dalam memperoleh pengalaman yang bermakna. Keempat, menyampaikan rangkuman atau ringkasan tentang materi yang dibahas pada hari itu .

3) Observasi dan Evalusi Siklus I

Penilaian dilakukan dengan menilai tugas-tugas yang diberika, dan mengobservasi kegiatan belajar mereka. Hasil observasi/pengamatan disampaikan Gambar 2. 


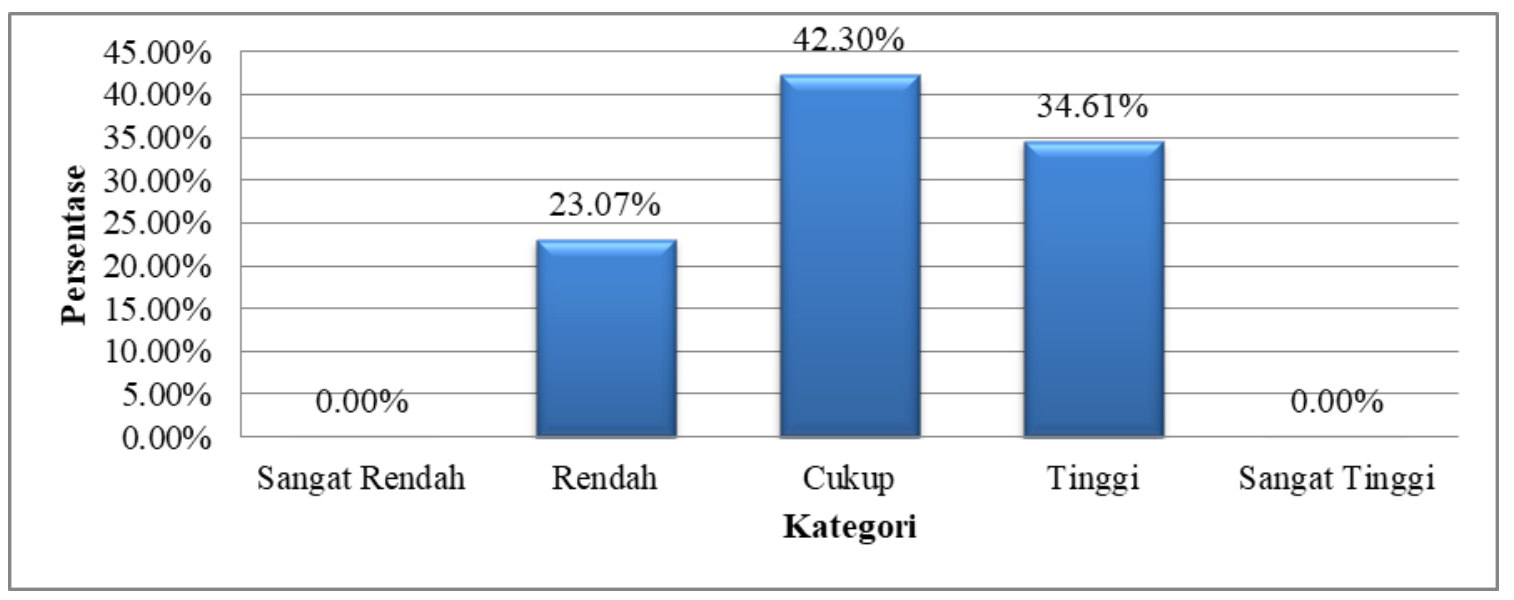

Gambar 2. Sebaran Prestasi Belajar Siswa Siswa pada Siklus I

Dari hasil analisis data prestasi belajar siswa pada siklus I terlihat bahwa nilai terendah adalah 50 dan nilai tertinggi adalah 78. Persentase banyaknya siswa yang nilai tes prestasi belajar siswa dalam kategori sangat rendah adalah $00,00 \%$ (0 orang), 23,07\% dalam kategori rendah (6 orang), $42,30 \%$ dalam kategori cukup (11 orang), 34,61\% dalam kategori tinggi ( 9 orang),dan 0,00\% dalam kategori sangat tinggi ( 0 orang). Jika dikategorikan berdasarkan nilai pretasi belajar siswa yang telah, maka rata-rata nilai pretasi belajar siswa tergolong kategori cukup. Berdasarkan analisis data di atas, dapat disimpulkan bahwa rata-rata nilai pretasi belajar siswa kelas VIII A3 SMP Negeri 3 Sawan pada siklus I belum memenuhi indikator keberhasilan, yaitu mencapai kategori tinggi sehingga masih harus ditingkatkan.

4) Refleksi Siklus I

Hasil Pada siklus I penerapan model pembelajaran ekspositori di kelas VIII A3 SMP Negeri 3 Sawan ini peneliti mengamati beberapa hal yang menyangkut proses peningkatan prestasi belajar pada pelajaran Agama Hindu. Proses pembelajaran yang dilaksanakan pada siklus I secara garis besar sudah sesuai dengan perencanaan yang dibuat. Walaupun demikian, masih perlu direfleksi dan dipertimbangkan sebagai perbaikan pada siklus berikutnya.

Adapun kendala-kendala yang ditemui pada pelaksanaan tindakan siklus I adalah sebagai berikut.

1) Pada awal pelaksanaan tindakan, siswa masih bingung dan masih sulit beradaptasi dengan situasi pembelajaran yang cenderung menuntut siswa lebih aktif bertanya dibandingkan kegiatan pembelajaran sebelumnya.

2) Siswa belum bisa melakukan perannya sesuai pembelajaran yang telah digunakan dimana banyak dari mereka masih bersifat pasif dalam mengikuti pelajaran.

3) Materi yang disampaikan tergolong sulit sehingga antusiasme siswa belum dapat diharapkan secara maksimal.

4) Siswa masih ada yang senang bermain main.

Berdasarkan kendala-kendala yang dihadapi pada siklus I, maka dilakukan perbaikan-perbaikan pada pelaksanaan tindakan yang selanjutnya diterapkan pada siklus II sebagai berikut.

1) Memberikan motivasi kepada siswa untuk dapat beradaptasi dengan situasi pembelajarana yang cenderung menuntut siswa banyak bertanya agar diskusi interaktif dapat berjalan.

2) Peneliti giat dan terlibat dalam pembelajaran sehingga materi yang sulit akan terasa mudah.

3) Peneliti lebih mampu mengatur siswa dan menciptakan pembelajaran yang menarik agar siswa mampu ikut dalam pembelajaran yang dilaksanakan sehingga siswa yang bermain dapat terminimalisir.

Pembelajaran pada Siklus II

1) Rencana Tindakan Siklus II

Rencana tindakan pada Siklus II meliputi:

1) Guru selaku peneliti merencanakan untuk melakukan penelitian dari bulan Januari sampai bulan Maret pada semestergenap.

2) Guru selaku peneliti merencanakan untuk memperbaiki prestasi belajar agama hindu yang masih di bawah KKM memanfaatkan model pembelajaran Ekspositori. 
3) Untuk memperdalam pemahaman tentang model dan metode yang akan diterapkan, guru selaku peneliti melakukan pengkajian beberapa literatur yang sesuai dengan permasalahan yang akan diselesaikan.

4) Merencanakan pembelajaran yang mampu membangkitkan keinginan siswa ikut berpartisispasi.

2) Pelaksanaan Tindakan Siklus II

1) Melakukan pembelajaran inti explorasi dengan cara menjelaskan materi dengan jelas dan sistematis, mengontrol siswa agar tidak bermain- main, memberi informasi tentang materi yang di ajar dan memberi pembuktian terhadap materi kitab suci

2) Melakukan pembelajaran inti elaborasi dengan cara mengajak anak bertanya jawab tentang materi kitab suci, melaksanakan pembelajaran yang membangkitkan minat belajar yaitu dengan berdiskusi interaktif, memberi bimbingan terhadap jalannya diskusi dan menyuruh anak untuk mempresentasikan hasil yang sudah dikerjakan.

3) Melakukan pembelajaran inti konfirmasi dengan cara memberi bantuan untuk memecahkan masalah, memberi kesempatan berpikir pada siswa dan memberikan kesempatan bertanya kepada siswa yang sulit mengerti dengan memberikan tambahan waktu.

3) Observasi dan Evalusi Siklus II

Pelaksanaan tindakan siklus II disesuaikan dengan hasil refleksi pada siklus I. Pelaksanaan tindakan siklus II dilaksanakan dalam 3 kali pertemuan yaitu 2 kali pertemuan untuk pelaksanaan pembelajaran dan 1 kali pertemuan untuk pelaksanaan tes prestasi belajar siswa. Berdasarkan hasil analisis data prestasi belajar siswa pada siklus II dapat dilihat pada Gambar 3.

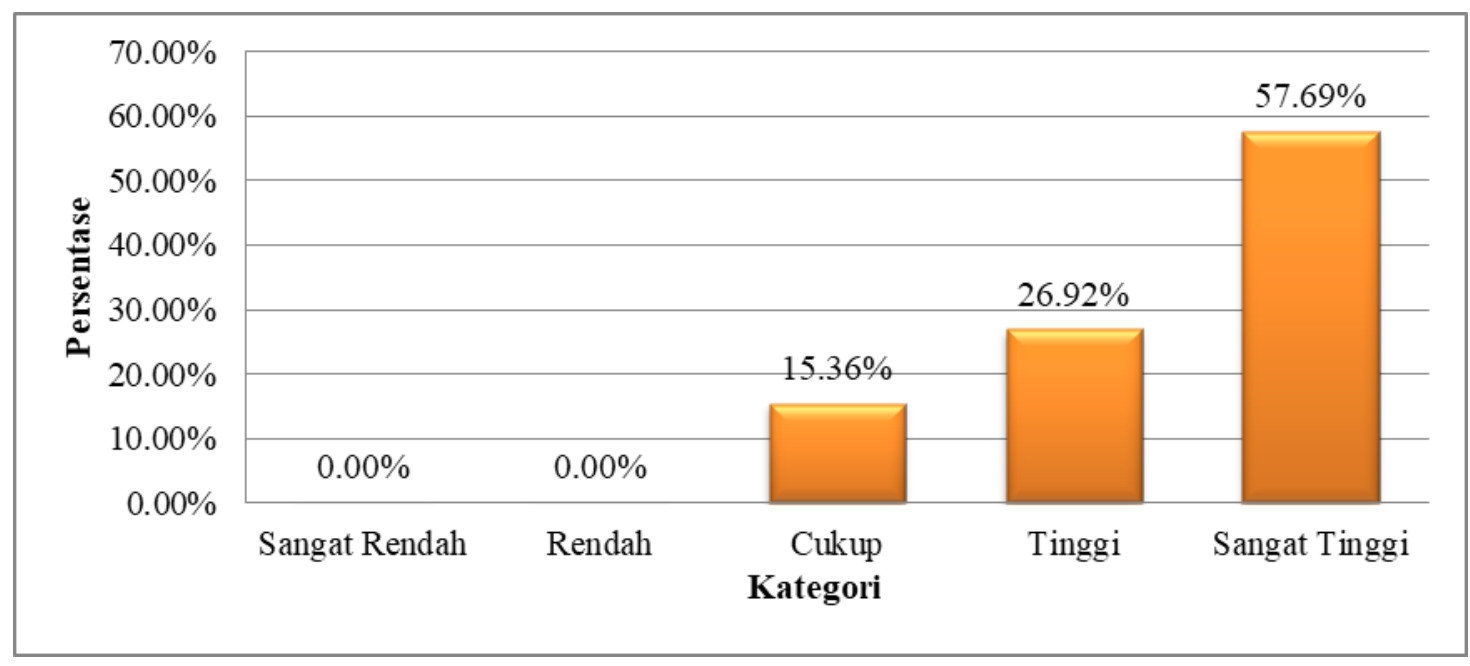

Gambar 3. Sebaran Prestasi Belajar Siswa pada Siklus II

Berdasarkan Gambar 3 terlihat bahwa nilai terendah siswa adalah 60 dan nilai tertinggi adalah 95,00. Persentase banyaknya siswa yang skor prestasi belajar siswa dalam kategori sangat rendah adalah $00,00 \%$ ( 0 orang), 0,00\% dalam kategori rendah ( 0 orang), 15,36 \% dalam kategori cukup (4 orang), 26,92\% dalam kategori tinggi (7 orang), dan 57,69\% dalam kategori sangat tinggi (15 orang). Jika dikategorikan prestasi belajar siswa, maka rata-rata skor tes prestasi belajar siswa tergolong kategori tinggi. Berdasarkan analisis data di atas, dapat disimpulkan bahwa rata-rata skor tes prestasi belajar siswa kelas VIII A3 SMP Negeri 3 Sawan pada siklus II sudah memenuhi indikator keberhasilan yang telah ditetapkan, yaitu mencapai kategori tinggi.

4) Refleksi Siklus II

Berdasarkan hasil refleksi siklus II terlihat bahwa pembelajaran pada siklus II, baik dari segi hasil maupun proses menunjukkan peningkatan dari siklus sebelumnya. Guru dan siswa sudah semakin terbiasa dengan kegiatan pembelajaran yang diterapkan. Siswa tampak sudah terbiasa mengikuti pembelajaran dengan model pembelajaran yang dilaksanakan guru. Suasana pembelajaran menjadi sangat nyaman dan terbuka, sebagian besar siswa sudah tidak banyak bermain-main, tidak pasif, dan siswa sudah berani mengajukan pertanyaan sehingga diskusi berjalan sesuai yang direncanakan dan kelas menjadi kondusif. Dari uraian di atas, dapat dikatakan bahwa pada siklus II tidak terdapat lagi permasalahan yang berarti dalam proses pembelajaran. 
Berdasarkan hasil yang diperoleh dari siklus I sampai siklus II tampak bahwa tingkat prestasi belajar siswa pada pelajaran Agama Hindu khususnya pada materi Veda sudah mencapai indikator keberhasilan, yaitu sudah berada pada kategori tinggi. Berdasarkan analisis data tingkat prestasi belajar siswa diperoleh rata-rata skor tes prestasi belajar pada siklus I adalah 67. Berdasarkan hasil analisis tersebut, rata-rata skor tes prestasi belajar siswa belum memenuhi indikator keberhasilan yang telah ditetapkan.

Belum tercapainya indikator keberhasilan yang telah ditetapkan untuk prestasi belajar siswa Kelas VIII A3 disebabkan oleh kendala-kendala yang terjadi selama pelaksanaan tindakan pada siklus I yang telah dipaparkan pada hasil refleksi siklus I. Kendala-kendala yang dialami siswa pada siklus I diantaranya siswa masih bingung dan masih sulit beradaptasi dengan situasi pembelajaran yang cenderung menuntut siswa lebih aktif bertanya dibandingkan kegiatan pembelajaran sebelumnya, siswa belum bisa melakukan perannya sesuai pembelajaran yang telah digunakan dimana banyak dari mereka masih bersifat pasif dalam mengikuti pelajaran, materi yang disampaikan tergolong sulit sehingga antusiasme siswa belum dapat diharapkan secara maksimal, dan siswa masih ada yang senang bermain main.

Kendala-kendala yang dialami tersebut kemudian didiskusikan oleh peneliti bersama guru untuk dicarikan solusinya. Melalui kegiatan refleksi ini, disepakati beberapa solusi yang dilaksanakan untuk mengatasi kendala-kendala tersebut sebagai bahan perbaikan untuk pelaksanaan tindakan pada siklus II seperti yang dipaparkan pada refleksi siklus I.

Perbaikan tindakan yang dilaksanakan ini ternyata dapat meningkatkan prestasi belajar siswa pada siklus II. Peningkatan ini dapat dilihat dari rata-rata skor tes prestasi belajar siswa pada siklus II sebesar 82,69. Namun, rata-rata skor tes prestasi belajar siswa belum mencapai indikator yang ditetapkan yaitu berada dalam kategori tinggi. Berdasarkan analisis data tersebut, rata-rata skor tes prestasi belajar siswa siswa kelas VIII A3 SMP Negeri 3 Sawan pada siklus II sudah memenuhi indikator keberhasilan yang ditetapkan.

Tercapainya indikator keberhasilan pada siklus II disebabkan karena proses pembelajaran pada siklus II ini sudah semakin baik dan sesuai dengan skenario yang direncanakan, dimana siswa semakin terbiasa dengan penerapan model pembelajaran ekspositori. Siswa tampak sudah terbiasa mengikuti pembelajaran dengan model pembelajaran yang dilaksanakan guru. Suasana pembelajaran menjadi sangat nyaman dan terbuka, sebagian besar siswa sudah tidak banyak bermain-main, tidak pasif, dan siswa sudah berani mengajukan pertanyaan sehingga diskusi berjalan sesuai yang direncanakan dan kelas menjadi kondusif.

Adapun beberapa usaha yang dilakukan selama pemberian tindakan untuk membantu meningkatkan motivasi belajar siswa diantaranya : (1) memberikan pengertian bahwa betapa pentingnya pelajaran Agama Hindu dalam kehidupan sehari-hari terutama kaitannya dengan pelajaran lain, serta kaitannnya dalam kehidupan sehari-hari, (2) menekankan kepada siswa bahwa untuk melatih pemahaman mereka terhadap konsep Veda sehingga, siswa haruslah selalu rajin untuk membaca materi sebelum pembelajaran dimulai dan melatih kemampuannya melalui latihan-latihan soal yang diberikan, (3) serta menekankan pada siswa jika ada hal yang kurang dimengerti bisa mengajukan pertanyaan kepada guru atau bisa aktif dalam dikusi yang dilakukan guru di kelas.

Model pembelajaran ekspositori dapat meningkatkan prestasi siswa dalam pelajaran Agama Hindu karena dalam pembelajaran ini secara umum terdapat beberapa tahapan pembelajaran yang lebih banyak menfasilitasi siswa dengan memberikan penjelasan dan konsep-konsep yang jelas. Pada tahap awal, siswa diberikan kesempatan untuk menetapkan/menentukan hasil belajar yang ingin dicapai melalui pencapaian tujuan yang diberikan oleh guru. Untuk mencapai tujuan yang telah ditentukan tersebut, guru memberikan motivasi pada siswa.

Tahap kedua yaitu tahap inti. Pada langkah inti ni, Guru menyampaikan materi dengan ceramah, tanya jawab, dilanjutkan demonstrasi untuk memperjelas konsep terkait materi yang dijelaskan yaitu terkait dengan materi Veda. Kemudian Guru memberikan kesempatan bagi siswa untuk bertanya sehingga terjadi diskusi dalam kelas (diskusi interaktif). Serta memberikan latihan-latihan soal setelah melakukan penyampaian materi.

Tahap terakhir yaitu Penutup. Pada tahap ini dilakukan penyampaian kesimpulan mengenai materi yang telah dipelajari. Selain itu, dilakukan juga klarifikasi apabila masih ada yang kurang dimengerti dan yang masih memiliki kekeliruan. Kemudian dilakukan evaluasi maupun tugas-tugas untuk dikerjakan di rumah agar siswa terlatih kembali saat dirumah.

Berdasarkan hasil yang diperoleh, penelitian ini secara umum telah mampu menjawab rumusan masalah sekaligus telah mampu memecahkan permasalahan rendahnya prestasi belajar siswa yang dimiliki oleh siswa dalam pembelajaran Agama Hindu. Penerapan Model pembelajaran ekspositori dengan bantuan diskusi interaktif ini dapat meningkatkan prestasi belajar siswa kelas VIII A3 SMP Negeri 3 
Sawan. Hal ini juga didukung oleh tanggapan positif siswa terhadap pembelajaran yang dilaksanakan. Dengan kata lain penelitian tindakan kelas yang dilaksanakan berhasil.

\section{Simpulan dan saran}

Berdasarkan uraian fakta-fakta di atas yang didukung dengan penyajian data hasil obsevasi baik siklus I maupun siklus II yang disampaikan sudah dapat dibuktikan bahwa model Pembelajaran ekspositori dengan diskusi interaktif dapat meningkatkan kemampuan siswa dalam belajar yang berdampak pada peningkatan prestasi belajar siswa kelas VIII A3 SMP negeri 3 Sawan. Dengan hasil tersebut dapat dibuktikan bahwa rumusan masalah dan tujuan penelitian telah tercapai dan hipotesis yang diajukan sudah dapat diterima.

Selanjutnya perlu disampaikan saran bagi guru mata pelajaran, apabila mau melaksanakan proses pembelajaran penggunaan model yang telah diterapkan ini semestinya menjadi pilihan dari beberapa model yang ada mengingat model pembelajaran ekspositori telah terbukti dapat meningkatkan prestasi belajar siswa.

\section{Daftar Rujukan}

Arikunto, S., Suhardjono dan Supardi. 2006. Penelitian Tindakan Kelas. Jakarta: PT Bumi Aksara.

Buana RM, Kartika. 2018. PENERAPAN MODEL PEMBELAJARAN INQUIRI SEBAGAI UPAYA UNTUK MENINGKATKAN PRESTASI BELAJAR PENDIDIKAN AGAMA HINDU. Jurnal Ilmu Pendidikan. Vol.1, No.1.

Dedi Hermawan, Kadek dkk. 2017. Relevansi Nilai Pendidikan Karakter Dalam Geguritan Suddhamala Untuk Meningkatkan Mutu Pendidikan Di Indonesia. Jurnal Penjaminan Mutu, Vol.3, No.2.

Depdiknas. 2011. Membimbing Guru dalam Penelitian Tindakan Kelas. Jakarta: Pusat Pengembangan Tenaga Kependidikan Badan Pengembangan Sumber Daya Manusia Pendidikan dan Menjaminan Mutu Pendidikan.

Desmawati. 2017. Peningkatan Hasil Belajar Ekonomi Melalui Metode Ekspositori Pada Siswa Kelas XI IPS 3 SMAN 1 Koto Balingka. Education and Policy in Social Science, Vol.1, No.2.

Soejono dan Abdurrahman, H. 2003. Metode Penelitian Hukum. Jakarta: PT Rineka Cipta.

Sudjana, N. 2002. Penilaian Hasil Proses Belajar Mengajar. Bandung: PT Remaja Rosdakarya.

Sanjaya, W. 2006. Strategi Pembelajaran Berorientasi Standar Proses Pendidikan. Jakarta: Kencana Prenada Media.

Hidayat, O. S. 2007. Metode Pengembangan Moral dan Nilai-nilai Agama. Jakarta: Universitas Terbuka.

Hildayani, R.. 2008. Penanganan Anak Berkelainan. Jakarta: Universitas Terbuka.

Iriyanto, H.D. 2012. Hebat Gurunya Dahsyat Muridnya. Jakarta: Erlangga.

Kunandar.2008. Langkah Mudah Penelitian Tindakan Kelas Sebagai Pengembangan Profesi Guru. Jakarta: Rajawali Pers.

Lestari, Suci. 2018. Penerapan Metode Pembelajaran Diskusi Dan Resitasi Dalam Meningkatkan Hasil Belajar Pendidikan Agama Hindu Siswa Kelas Iv Sd Negeri 2 Tumbu Karangasem. Jurnal Penjaminan Mutu, Vol.4, No.1

Prastiwi, R. 2010. Buku Tematik Peduli Lingkungan. Jakarta: PT. Gramedia Widiasarana Indonesia.

Purwanto, N. 1997. Psikologi Pendidikan. Bandung: Rosdakarya. 
Sahertian, Piet, A dan Sahertian, A. 1992. Supervisi Pendidikan dalam Rangka Program Inservice Education. Jakarta: Rineka Cipta.

Sardiman, A.M. 1988. Interaksi dan Motivasi Belajar-Mengajar Pedoman bagi Guru dan Calon Guru. Jakarta: Rajawali Pers.

Slavin, R. E. 1995. Cooperative Learning : Theory, Research, and Practice. Boston: Allyn and Bacon.

Suhardjono. 2010. Pertanyaan dan Jawaban di Sekitar Penelitian Tindakan Kelas dan Penelitian Tindakan Sekolah. Malang: Cakrawala Indonesia.

Sudarsana, I. K. (2017, October). Pengembangan Pendidikan Berbasis Kearifan Lokal Untuk Mewujudkan Toleransi Antar Umat Beragama. In Prosiding Seminar Nasional Filsafat (pp. 216-223).

Sudarsana, I. K. (2017, October). Peranan Orang Tua Dalam Penanaman Budi Pekerti Pada Anak. In Prosiding Seminar Nasional Anak Usia Dini (SEMADI) 2 (pp. 157-160).

Sudarsana, I. K. 2017. Interpretation Meaning of Ngaben for Krama Dadia Arya Kubontubuh Tirtha Sari Ulakan Village Karangasem District (Hindu Religious Education Perspective). Vidyottama Sanatana: International Journal of Hindu Science and Religious Studies, Vol. 1, No. 1.

Wiguna, I. M. A. (2017, October). Memaknai Mahavakya Sebagai Bentuk Universalitas Veda Dalam Upaya Membangun Semangat Kebhinekaan. In Prosiding Seminar Pendidikan Agama (pp. 93-102). 